\title{
"Blue" social capital and work performance: anthropological fieldwork among crew members at four Danish international ships
}

\author{
Sisse Grøn • Gunnar Lind Haase Svendsen
}

Received: 27 September 2012 / Accepted: 27 February 2013 / Published online: 28 March 2013

(C) The Author(s) 2013. This article is published with open access at Springerlink.com

\begin{abstract}
One outcome of globalization is an increasing number of seafarers, who seldom are members of the same crew two voyages in a row and must cooperate with seafarers from many countries (Progoulaki and Roe WMU J Marit Affairs 10:7-23, 2011). This situation challenges the level of social capital on board, i.e., the resources inherent in network cooperation associated with norms of reciprocity and trust (Putnam 2000: 19). Fragmentized "blue" social capital should, however, be restored, as work performance depends on the quality of cooperation among crew members horizontally, as well as between crew members and the shipping company vertically. Drawing on anthropological fieldwork data from four Danish international ships, the purpose of this paper is to offer a new theoretical framework for analyzing cooperation among crews. Our inductive empirical findings suggest that a balance between three types of social capital — bonding, bridging and linking - is needed to achieve a high-performing work system (Gittell et al. Organ Sci 21(2):490-506, 2010). Hence, the main actors within the shipping sector should take "blue" social capital into account to increase work efficiency and economic performance.
\end{abstract}

Keywords Social capital $\cdot$ Shipping $\cdot$ Work performance $\cdot$ Trust $\cdot$ Maritime $\cdot$ Safety

\section{Introduction}

A seafarer's workplace has never been confined to his or her homeland, but today seafaring is more globalized than ever, and the worldwide structure of seafaring allows any seaman to be instantly replaced by another. Therefore, seafarers are

S. Grøn

Centre of Maritime Health and Safety, University of Southern Denmark, Esbjerg, Denmark

e-mail: smfg@cmss.sdu.dk

\section{G. L. H. Svendsen $(\bowtie)$}

Danish Centre for Rural Research, Institute of Environmental and Business Economics,

University of Southern Denmark, Esbjerg, Denmark

e-mail: glhs@sam.sdu.dk 
seldom members of the same crew two voyages in a row and are forced to cooperate with seafarers from many countries whom they do not know and whose primary language they may not understand (Progoulaki and Roe 2011). This situation challenges the level of social capital on board - that is, those invisible resources with visible socio-economic effects that are encapsulated in network cooperation and associated with norms of reciprocity and trust (Putnam 2000: 19). Drawing on anthropological fieldwork conducted in 2010 and 2011 on four international Danish ships, we address the following question: How can the fragmentation of "blue" social capital due to globalization be counteracted?

\subsection{The case of Denmark}

In a country such as Denmark, increased globalization presents the challenge of adjusting legal procedures and policies to accommodate foreign citizens working in Danish workplaces. This situation particularly affects the large Danish shipping sector, in which globalization has led to two major changes during the last 25 years. In 1988, the Danish International Ships Register (DIS) was launched to optimize Denmark's competitive position in the world market. Most importantly, the DIS contained an organizational change that allowed Danish ships to compete with "flags of convenience" on a more equal footing. After World War II, the widespread use of convenience flags allowed ship owners to register in their country on more favorable terms in relation to crewing, taxes, and mandatory regulations. Since 1988, the DIS has allowed shipping firms under the Danish flag to employ seafarers on foreign contracts. Consequently, the wages, the duration of the contracts, and the forms of employment differ between seafarers of various nationalities, even if they perform the same job. Moreover, the Danish Maritime Authorities have recently introduced another tool in their attempt to adapt to globalization, namely, the removal of a previous requirement of the presence of a Danish officer on all crews. Now one European officer is sufficient, and there are also exceptions such that full crews of, for instance, Indian or Filipino seafarers may be accepted.

\subsection{The risk of fragmentation}

Increasing globalization can also be seen today the fact in that the organizations of most shipping companies are dispersed all over the globe, with owners in one country, commercial managers in another, and crew managers in a third, while the vessel itself is always on the move (Lane 1996; Sampson 2012). Due to these many diverse parts and sub-parts within a shipping business, things can easily become fragmentized, uncoordinated, or simply chaotic. Hence, leaders within the shipping sector need to build social coherence in the form of inter-group relationships based on trust and reciprocity within their organization, that is, social capital. Such time-labor investments render real revenues; that is, they are capitalizable (into economic capital). Hence, maritime or "blue" social capital may be capitalized as, e.g., better vertical (shipping company-crew) and horizontal (relations on board) communication, cooperation and coordination, as well as enhanced security and productivity. At the micro level-from the perspective of the single seafarer-things are no less fragmentized and confused. Most seafarers have a number of principals to answer 
to: the owner, the manning agency and, in some cases, also the management agency. On top of this, seafarers find themselves confined to a ship with people upon whom they depend and with whom they work closely but with whom, in most cases, they cannot become too involved because they only work together for a short period.

\subsection{Strengthening "blue" social capital}

All this fragmentation challenges the cooperative relationships both within the shipping organization and on board among the crew. A decrease in cooperative skills can be very costly for a shipping company, as cooperation is a must in the microcosm confined to a ship, not least for the sake of safety. As Schröder-Hinrichs et al. (2012) have argued, it is crucial that authority gradients allow for all crew members to take part in the decision process if they suspect that the higher-ranking officers are compromising safety. Therefore, increasing cooperative skills within a crew specifically, and in a shipping company generally, should be viewed as an extraordinarily important resource for "lubricating" cooperation among employees, enhancing psychological well-being and safety on board and, ultimately, improving work performance and profitability. Therefore, smooth and effective cooperation should rightly be recognized as a form of capital - a form of social capital, defined as the resources inherent in network cooperation associated with norms of reciprocity and trust (Putnam 2000: 19). Social capital is arguably even more important in business at sea compared with business on shore - in line with physical capital in the form of the ship, the radar equipment, the safety boat, the containers, etc., and human capital in the form of a well-educated crew. As mentioned, we may in fact talk about maritime or "blue" social capital at a meso- (organizational) level. This term is appropriate as, even more than on shore presumably, social capital at sea contributes significantly to increasing the economic performance of a shipping company.

\subsection{Purpose and contribution}

Hence, in drawing on anthropological fieldwork data from four Danish international ships, the purpose of this article is to shed more light on "blue" social capital by answering the following question: How can fragmentation of "blue" social capital due to globalization be counteracted? To answer this question, we offer a new theoretical framework for understanding the dynamics of cooperation (or noncooperation) among crew members by mapping configurations of "blue" social capital and relating them to work performance.

By "configurations of social capital", we refer to combinations of various types of social capital. Here, our inductively attained data indicate that a balanced combination between three types of social capital is needed to achieve a high-performance work system (Gittell et al. 2010). These three types are bonding (BO) and bridging (BR) social capital, which are categorized as horizontal networks, and a subtype of $\mathrm{BR}$, namely linking social capital (LI), which is categorized as vertical networks that go across formal or institutional power positions (e.g., the relation between a politician and a representative of a voluntary association in a local community) (Woolcock 1998, 2001; Putnam 2000; Szreter and Woolcock 2004). All three types can take a positive, economically productive form and should rightly be termed capital, as well 
as a negative, economically counterproductive form and should therefore be termed privatized capital, or not capital. In this article, we crudely operationalize vertical types of networks (LI) as networks between crew members of all ranks on board and the ship owner and/or shipping company on shore, while horizontal types (BO and BR) consist of networks on board the vessel (except if the owner and captain are the same person). Overall, we advise the main actors within the shipping sector to value and further develop cooperative skills among shipping employees as an important form of capital — "blue" social capital — and, in addition, to try to obtain a balanced mix of BO, BR, and LI types of social capital within a single crew.

\subsection{Outline}

The article is structured in the following way: Section 2 outlines those findings within social capital research that seem most relevant to "blue" social capital, links them to the shipping sector and finally describes the three types of social capital (BO, BR, LI). Section 3 presents cases. First, we describe methodology, then we describe and analyze social capital on board four Danish international vessels. Section 4 sums up our empirical and theoretical findings.

\section{Social capital}

Why is social capital important for work performance at sea? After a brief introduction of the concept, we will, in the following point to three crucial elements of social capital that have dominated this strand of research, namely, trust, collective action and reputational effects (see, e.g., Svendsen and Svendsen 2009). Then, we will describe the three types of social capital — bonding, bridging and linking — and relate them to "blue" social capital.

\subsection{Introduction: capital, social capital and reciprocity}

\subsubsection{Capital and intangible assets}

According to the founding father of economics, Adam Smith, "capital" (from Lat. caput, head, head sum) refers to stored wealth that affords its owner revenues. Capital allows us to produce services or goods for consumption without the means of production (immediately) being destroyed itself - as in the case of a machine that produces spare parts for cars, or a container ship bringing goods from one place in the world to another. Unlike such tangible forms of capital, intangible forms of capital (Veblen 1908a, 1908b) tend to increase with use, as in the case of human capital (useful knowledge) or social capital (networks). The more you use them, the more you receive from them.

\subsubsection{The economic value of reciprocity}

The idea of social capital is of course not new. Most clearly, perhaps, it reflects the old anthropological concept of "reciprocity" (Lat. reciprocus), which means returning 
back the same way-where re means back and pro forward - for example, giving a favor or a gift. This quid pro quo principle implies that if I help you today, I expect you to help me tomorrow. As Gouldner (1960: 172) explains, reciprocity might take the form of either tit for tat (that is, exchanging non-similar items, or heteromorphic reciprocity) or tat for tat (homeomorphic reciprocity). Historically, the term is closely connected to the functionalist approach within social anthropology and sociology. In a seminal paper on "the norm of reciprocity", Gouldner (1960) traces the concept back to the anthropologist Bronislaw Malinowski, who contended that, in primitive societies, reciprocity could be observed as people perpetually owing obligations to each other. This phenomenon happened due to a "mutual dependence", which was "realized in the equivalent arrangement of reciprocal services" (Malinowski in Gouldner 1960: 169). Within sociology, Simmel likewise saw this principle as a way to maintain social cohesion and that "all contacts among men rest on the schema of giving and returning the equivalence" (Simmel in Gouldner 1960: 162). Gouldner himself sees the universal rule of reciprocity - a so-called principal component, which always appears as a norm dressed in various cultural clothings - as an alternative, informal and extremely flexible way to regulate human behavior. Hence, reciprocity is able to supplement, or even substitute, rules of behavior of a more institutionalized and contractual nature, and which is based on unequal power relations and, often, exploitation. At the empirical level, reciprocity can be seen as "a pattern of mutually contingent exchange of gratifications", which makes people "socially indebted" and, hence, interlinked (Gouldner 1960: 161). If reciprocity is not of a negative nature (e.g., wish of vengeance, or strongly asymmetrical reciprocity), it unites the creditor and the debtor and in this way contributes to the production of social glue in a society. All in all, Gouldner views the term "reciprocity" as a mediator-if not the missing link-between a Marxist tradition that is focused on conflict, exploitation and asymmetrical reciprocity; and a Durkheimian tradition that is concerned with the division of labor, consensus and social cohesion, i.e. symmetrical reciprocity, thus paving the way for Lévi-Straussian structuralism (Gouldner 1960: 167).

Within academia, terms such as "reciprocity", "gift-giving" (Mauss 1969 [1925]) and "the rule of distributive justice" (Homans 1961; Blau 1964) have prevailingly been linked to cultural and social phenomena, although a calculating, economizing tendency has often been admitted. ${ }^{1}$ Filling this gap in terminology within the field of economic sociology, "social capital" is designed to underline the economic gains and motivations of reciprocity not just for the single individual but also for groups or whole nations. Hence, the word "social" from the cultural and "non-economic" realms of sociology and anthropology has been combined with the word "capital" from economics in an attempt to express the invisible socio-economic nature of human relations and interaction (Coleman 1994: 175), or what the founder of socio-economics Amitai Etzioni (2003) has termed "the socio-economic mind". Originally a sociological term, social capital has increasingly been adopted by economists, not least since the seminal article "Does social capital have an

\footnotetext{
${ }^{1}$ For example, Homans saw social behavior as "an exchange of activity, tangible or intangible, and more or less rewarding or costly, between at least two persons", comprising agents who expect economic or symbolic rewards in proportion to their labor-time investments and, besides, get angry if such justice is violated (Homans in Blau 1964: 193). See also Emerson (1976) for a review of the social exchange theories of Homans, Blau and others.
} 
economic pay-off?" by Knack and Keefer (1997), in which they showed that social capital operationalized as social trust - that is, trust to strangers ${ }^{2}$ - could explain a considerable part of economic growth in a group of 27 countries. $^{3}$

\subsubsection{Social capital definitions}

Social capital can be studied at the micro, meso and macro levels. A famous definition of social capital with relation to the single individual is offered by Bourdieu (1986: 248-49), who defines social capital as "the aggregate of the actual or potential resources which are linked to (...) membership in a group". From such a perspective, building and using social capital prevailingly reflects the provision of private goods at the micro level. However, most scholars have been interested in social capital as a tool for the provision of collective goods, including solving collective action problems. In particular, studies have been undertaken at a mid-level, where social capital has been seen as a resource belonging to an organization, e.g., a lobby group, a voluntary association, a public institution, or a private enterprise - that is, what has also been termed organizational social capital (see Svendsen and Waldstrøm 2013 for a review). Social capital can however also be studied as an important resource for whole nations, as smooth inter-group cooperation between trusting and trustworthy citizens - at work places, at public places and in the civic society-is supposed to "lubricate" the economy (Putnam 1993, 2000).

One of the leading scholars within social capital research, American political scientist Robert D. Putnam, has argued in the following way for the somewhat controversial "marriage" between the terms "social" and "capital" and, in essence, between the cultural sciences and economics: "Just as a screwdriver (physical capital) or a college education (human capital) can increase productivity (both individual and collective), so too social contacts affect the productivity of individuals and groups" (Putnam 2000: 19). Unlike Bourdieu, Putnam defines social capital as primarily a collective good that should seriously be taken into account by governments and organizations, and which consists of three core elements: "features of social organization such as networks, norms, and social trust that facilitate coordination and cooperation for mutual benefit" (Putnam 1995: 67). As we find that this definition best captures the most crucial elements of "blue" social capital-networks, norms and trust for mutual benefits-we will use this definition throughout the article. However, before proceeding to the first of the three types of social capital, i.e., the network element, we will use some space to explore three topics in the social capital literature because they appear to be of particular interest in our context: trust, collective action dilemmas, and reputation.

\footnotetext{
${ }^{2}$ Also termed generalized trust, in contrast to particularized or specific trust, which is trust of people you already know. Since the 1950 s, generalized trust has mostly been measured by the standard question, "In general, do you think most people can be trusted, or can't you be too careful?" that is used, for example, in large questionnaire surveys as the World Values Surveys.

${ }^{3}$ See Bjørnskov (2009) for a review of social capital and economic growth. We may also mention that the term has been adopted by The World Bank, in an attempt to measure and build intangible assets in local communities in Third World countries and thus stimulate economic growth - see e.g., Dasgupta and Serageldin (2000); Grootaert and Bastelaer (2002); Dudwick et al. (2007).
} 
2.2 Trust, collective action, and reputation

\subsubsection{Trust}

Trust is an indicator of social capital. If two persons, or a group of people, trust each other and in fact can trust each other, it will be easier for them to engage in productive collaboration, as such collaboration will be characterized by low transaction costs, including agency costs. Take, for example, the importance of trust between groups of crew members (Filipinos, Indians, Europeans, etc.), or between a captain and crew members who are "in the same boat," so to speak, and a ship owner and/or the directing board of the shipping company. To trust is to accept vulnerability because you are never sure whether the other can be trusted or whether the partner will abuse your trust. In this sense, vulnerability is the "price of trust" (Barbalet 2009: 369), implying potential economic, social and emotional costs (see also Huang and Fox 2006: 260).

However, it is important to add that supra-individual factors impact trust. From a rational choice perspective, risks of being hurt are on the one hand conditional on people's daily life experiences, including experiences with personal acquaintances and with other ways to seek information. On the other hand, cheaters and free riders run the risk of sanctions, either in the form of social sanctions or more formal sanctioning from the state or the organization, at the meso- and macro levels (e.g., the cooperative enterprise) (cf. Coleman 1990; Cook et al 2005; Newton 2007; Rothstein 2002, 2009).

Within the shipping sector, take the example of a captain who is two-faced and says that safety is his top priority, while in reality he encourages the crew to cut corners. As this is gradually discovered by crew members, general distrust, conflicts and lack of coordination and cooperation on board may well arise and destroy social capital. The consequence would be not only that people's feelings are hurt, but it is also likely that work performance would decrease, as well as profitability. Take also the example of a chief marine engineer who free rides by delegating all of his work to his assistants. This person may risk social sanctions, such as social exclusion, gossip, and the like.

\subsubsection{The importance of norms and rules for collective action}

It is, however, an oversimplification when Huck (1998:55) states that it is only when costs from sanctions exceed profits from cheating that "trustworthiness pays off". Findings on collective action within behavioral and evolutionary game theory show that narrow self-interest is moderated by social motivations and history (repeated games). Moreover, there is, in general, more willingness to cooperate in one-shot games in which the trustor has very little, or no, information about the trustee than was previously assumed in first-generation collective action theories (Ostrom and Ahn 2009: 19-20). Without leaving the rational actor model behind entirely, secondgeneration collective action theories have acknowledged the existence of "multiple types of individuals" with "intrinsic values" (not only the average rational actor) and that cooperative outcomes are influenced by individual personalities and interests, social networks, trust and rules, including the possibility of social sanctioning (Ostrom and Ahn 2009: 21). 
These underlying norms of reciprocity and trust within a group or firm, and the concomitant formal or informal rules to ensure them, have often been identified as social capital (Coleman 1990; Ostrom and Ahn 2009). It is assumed that social capital contributes to solving collective action problems, i.e., it helps in mediating conflicts between private and collective interests, including solving the free rider problem. Moreover, social capital strengthens the other forms of capital within the group (physical, financial, human) in having a multiplier effect. If we return to the shipping example, the captain would most likely not lie and the engineer not free ride if strong formal and/or informal rules forbade them to do so and if they ran a high risk of severe punishment such as, for example, losing their jobs. Hence, we see the importance of explicit rules as well as more informal rules (norms) in solving collective action problems, i.e., securing that the rule of law enforces that no one cheats and that all participate in "fair" and transparent cooperation, in which all crew members do their share of the work.

\subsubsection{Reputational effects}

Finally, risk of the specific social sanctioning of getting a bad reputation is in play among crews - although increasing mobility and internationalization arguably weakens the effect (if a seafarer never joins the same crew two journeys in a row, it may never harm him that he has obtained a bad reputation). In other words, reputational effects play a role in social capital generally and, for configurations of the three types of capital, specifically (e.g. Hardin 2002).

To the extent that a shipping company, for example, enjoys social capital, the business partners are more likely to comply with agreements, trusting each other rather than spending time and energy on costly control and monitoring. Social capital among the staff means that the work is better coordinated and that there will be fewer free riders. Instead, employees, further motivated by the ownership and an institutional setup that secures fairness, will work for mutual benefits instead of solely looking after their own narrow individual or (sub-) group interests. If the customers have trust in, e.g., a shipping firm or a singlecontainer ship crew, they are willing to pay a higher price and buy more journeys. When the capital market has a positive view of the firm, more investors are interested, and they are willing to buy more stock at a higher price and lend more money on terms that are better for the firm. A firm with a good reputation is likely to attract more qualified staff. Likewise, at the micro level, seafarers would have an interest in guarding their reputation. Take again the chief engineer mentioned above. If a rumor goes around that he is lazy and delegates his all work to assistants, he might have difficulty in getting a job elsewhere or simply keeping his current job.

2.3 Network configurations: types and quality of social capital in organizations

How can we identify and analyze "blue" social capital? So far, we have identified and explained some important sources of social capital and effects connected to two key 
elements of social capital, cf. Putnam's definition (1995: 67), namely, trust and cooperative norms, as well as the rules and sanctions that ensure cooperation for mutual benefits. We now turn to what social capital really is, namely, social relations used for socio-economic purposes, i.e., the third element of networks.

\subsection{1 "Blue" social capital: important questions}

Social capital is often said to be different from other forms of capital in that it is not strictly the property of any individual or entity because it only exists in intangible and invisible relations between individuals. For example, although Bourdieu stresses that social capital can only be tapped by individual members of a network, he also describes social capital as "collectively-owned capital" (Bourdieu 1986: 249). This description raises important questions: Who owns a stock of social capital? Who actually uses it — and, potentially, at the cost of whom? Which types of social capital are built (configurations), and what does that mean for the productivity of a social capital stock?

As mentioned, in an organizational setting, social capital has mostly been studied under the assumption that it belongs to a group of people (often, an organization) and not to single individuals. This view does not exclude the possibility that single members - seen from a rational actor perspective - seek to capitalize upon their social capital out of sheer self-interest and may harm the common good in doing this, not least if the "rules of the game" that secure collective good provision are nonexistent as well. Hence, in the shipping context, we may ask, does social capital belong to the single Able Bodied seafarer (AB), who can capitalize upon his networks for his own sake? Or does it belong to the crew? Or to the shipping company? Or to all these actors?

To shed more light on the gains and costs of networking, we will turn to what we find is a fruitful framework for analyzing "blue" social capital - the triad of bonding, bridging, and linking social capital. In applying the framework to our cases, we will, as mentioned, operationalize horizontal networks as two types of social capital on board a ship: BO and BR social capital. Although power relations and social distance of course exist among a crew, crew members are still "in the same boat", do not own the boat and, hence, hold no decisive power. They meet each other regularly, or daily, and relations may therefore be assumed to be equal in the sense that they are all under the control of the owner/company. We will, therefore, for analytical reasons, regard all social relations on board as horizontal. An exception is of course when the owner and captain is the same person. In that case, relations to the captain/owner will be analyzed as linking social capital. Vertical types of networks transgressing formalized power relations will be analyzed as linking social capital (LI), that is, a subtype of BR that is operationalized as relations between crew members of all ranks on board the ship and the ship owner and/or shipping company on shore. All three types of social capital can have both positive and negative macro-economic effects (see Table 1 for an overview). Note that here we are talking about ideal types, which can never be found in any "pure" form in real life but are always in various mixes or, in our terminology, configurations of types of social capital. 


\subsubsection{Horizontal networks: positive and negative bonding and bridging social capital}

A forerunner to BR and BO is the seminal paper by Granovetter (1973) on the strength of "weak" ties. He argued that this type of relationship acted as a

Table 1 Three types and two qualities of social capital/social networks

\begin{tabular}{|c|c|c|}
\hline \multirow[t]{2}{*}{ Type } & \multicolumn{2}{|l|}{ Quality } \\
\hline & Positive & Negative \\
\hline Bonding & $\begin{array}{l}\text {-Horizontal relations } \\
\text {-Excluding networks } \\
\text {-Shared identity } \\
\text {-Based on specific trust } \\
\text {-Networks of people who regard themselves } \\
\text { as similar (homogeneous groups) } \\
\text {-Intra-group cooperation } \\
\text {-Bottom-up initiated } \\
\text {-Social safeguards for individuals } \\
\text {-Capital for individuals, groups and societies }\end{array}$ & $\begin{array}{l}\text {-Horizontal relations } \\
\text {-Excluding networks } \\
\text {-Shared identity } \\
\text {-Based on specific trust } \\
\text {-Networks of people who regard themselves } \\
\text { as similar (homogeneous groups) } \\
\text {-Intra-group cooperation } \\
\text {-Bottom-up initiated } \\
\text {-Only capital for certain individuals and } \\
\text { groups ("privatized" capital) } \\
\text {-Low out-group trust } \\
\text {-Economically harmful to societies }\end{array}$ \\
\hline Bridging & $\begin{array}{l}\text {-Horizontal relations } \\
\text {-Inclusion } \\
\text {-Diverse identities } \\
\text {-Based on social trust (high out-group trust) } \\
\text {-Networks of people who know they are not } \\
\text { like each other (heterogeneous groups) } \\
\text {-Inter-group cooperation } \\
\text {-Bottom-up initiated } \\
\text {-Capital for individuals, groups and societies }\end{array}$ & $\begin{array}{l}\text {-Horizontal relations } \\
\text {-Inclusion } \\
\text {-Diverse identities } \\
\text {-Based on social trust (high out-group trust) } \\
\text {-Networks of people who know they are } \\
\text { not like each other (heterogeneous groups) } \\
\text {-Waste of time } \\
\text {-Top-down initiated } \\
\text {-Social networks, not capital } \\
\text {-Superficial, arbitrary interaction } \\
\text { ("futile networking") } \\
\text {-Economically harmful to individuals, } \\
\text { groups and societies }\end{array}$ \\
\hline Linking & $\begin{array}{l}\text {-Vertical relations } \\
\text {-Inclusion } \\
\text {-Based on social trust (high out-group trust) } \\
\text {-Inter-group cooperation } \\
\text {-Interaction across formal, institutionalized } \\
\text { power relations } \\
\text {-Political influence } \\
\text {-Capital for individuals, groups } \\
\text { and societies }\end{array}$ & $\begin{array}{l}\text {-Vertical relations } \\
\text {-Inclusion } \\
\text {-Based on social trust (high out-group trust) } \\
\text {-Inter-group cooperation } \\
\text {-Interaction across formal, } \\
\text { institutionalized power relations } \\
\text {-Disorganization, poor coordination } \\
\text {-Corruption } \\
\text {-Only capital for certain individuals and } \\
\text { groups ("privatized" capital) } \\
\text {-Economically harmful to societies }\end{array}$ \\
\hline
\end{tabular}


concrete resource for individuals (e.g., job seekers). Granovetter also discussed social cohesion at the macro level, where "weak" bridging ties were found to be much more valuable than "strong" ties (e.g., family, close friends). Granovetter refers to these strong ties as cliques that may fragment a community and act as a barrier to collective action. Putnam (2000) was, however, one of the first to make the distinction between bonding and bridging social capital. He understood bridging social capital to be social relationships that are literally able to bridge between various groups, in line with Granovetter's "weak ties". 4 Putnam defined bridging social capital as open networks consisting of people who are unlike yourself and who are "outward looking and encompass people across diverse social cleavages" (Putnam 2000: 22). In contrast, bonding social capital consists of "inward looking [networks that] tend to reinforce exclusive identities and homogeneous groups" (Putnam 2000: 22). The latter implies not only care of family and friends but also, in extreme cases, "superglued" networks that consist of people who resemble each other (religion, social group, political conviction, occupation, etc.), are based on aggressive exclusion and are harmful to society; this phenomenon is called excessive bonding. Some examples of this type of bonding are the Ku Klux Klan, a terror cell, or a group of corrupt policemen. It is still capital that accrues revenues for its owners, but it is solely a form of privatized, "dark" social capital that, in contrast to, e.g., common family networks, is harmful to people outside the group and thus economically counterproductive for society as such (cf. Table 1).

Stocks of positive bridging social capital $(\mathrm{BR}+)$ and positive bonding social capital $(\mathrm{BO}+)$ are essentially beneficial to a group or an organization, which values them, has ownership of them and, consequently, can capitalize upon them (Table 1, left side). An example of $\mathrm{BR}+$ on board is smooth, trusting cooperation and communication among a container ship's crew that are conducive to a good work environment and productivity. A $\mathrm{BO}+$ example is strong inter-group trust and cooperation within ethnic groups on a container ship, accompanied by strong primary groups that do not harm other sub-groups. The example of the container ship illustrates that collaboration becomes-as a by-product (Coleman 1990) - a benefit for the whole firm, i.e., a collective good that can in principle be enjoyed by all employees in the shipping company in the form of widespread trust, cooperative norms, solidarity and loyalty, a good psychological working environment, information flow and, ultimately, improved economic performance.

However, as mentioned, these two types of social capital can also appear in exaggerated or excessive forms, or what has been termed "the downside of social capital" (Portes and Landolt 1996). This downside includes negative bridging social capital $(\mathrm{BR}-)$ and negative bonding social capital $\left(\mathrm{BO}^{-}\right)$that are prevailingly harmful to individuals, groups and organizations, or whole societies economically (Table 1, right side). Negative bridging social relationships $(\mathrm{BR}-)$ mean that the time-labor investment in networking is not

\footnotetext{
${ }^{4}$ Think, for example, of a strongly heterogeneous population such as we find in the USA, where the saying “One from many' (E Pluribus Unum) is a national motto - something that reflects the need to build bridges between strongly diverse groups (Putnam 2007).
} 
profitable for the organization, the group or the individual; it might even be harmful in terms of significant opportunity costs. Human interaction across social, political, ethnic, age, gender, etc., divisions is substantial (a type of "everybody should cooperate with everybody" ideology), while at the same time, however, it is superficial, somewhat arbitrary and not necessary or needs-driven, as seen from the perspective of a shipping company's leaders. Hence, networking is mostly redundant, a sheer waste of time, and should therefore not be seen as capital for individuals, groups or nations, but rather as "futile networking" (Table 1). A simple example of BR- is a large passenger ship with a crew from all parts of the world. The captain is eager to integrate all crew members of all ranks and therefore uses many resources on organizing newsletters, a multitude of long staff meetings, internet meetings with the shipping company, etc. He seeks to build bridges; however, his efforts are counteracted by conditions out of his power. Hence, crew members may just waste their time, and networking may be futile and even counterproductive. Examples of BO- that destroy "blue" social capital are evidently more common. Imagine, for example, a "superglued" group of Poles that stick together and are almost unwilling to communicate or cooperate with certain other ethnic groups on board, such as Filipinos, Danes, or Indians. This effect may simply ruin the "blue" social capital of that crew and, in addition, lower work performance and safety on board.

\subsubsection{Vertical networks: linking social capital}

Finally, we argue that in an organizational context at least, we have to include a third type of capital in the analysis, linking social capital, which really should be seen as a subtype of bridging social capital because the two types are identical except that linking networks go across not only various socio-economic divisions but also across "explicit, formal or institutionalized power or authority gradients in society [and thus connected] across explicit "vertical" power differentials" (Szreter and Woolcock 2004: 655); cf. Table 1. An example of negative linking social capital (LI-) is poor (or no) communication and coordination between a ship and its shipping company, leading to costly misunderstandings. As in the case of $\mathrm{BR}-$, networking creates no gains for anyone and should therefore not be acknowledged as capital. One could, however, also imagine LI- in the form of a close, but highly corrupt, relationship between, say, the captain and the authorities (the shipping company or others), implying unclear rules of the game and unfair play. Similar to negative bonding social capital, LI- should in such a case be seen as capital, but a "privatized" capital that is harmful to all those who are not group members. Instead, positive linking social capital (LI+) in the form of effective communication and even, maybe, personal (but non-corrupt) relationships between representatives of the company and the crew membersthat is, across formal and institutionalized uneven power relations within the organization-allows for a high degree of trust as well as opportunities for the crew to exert a real influence on the company's policies and, ideally, on their own working conditions. 


\section{Cases}

\subsection{Methodology}

The empirical foundation of this paper is a project concerned with illuminating differences in the number of work accidents and in the safety practices of crew members of different nationalities; see Grøn and Knudsen (2012) for a detailed description of the project. The concept of social capital was drawn in to provide a central explanatory framework for the purpose of this article because the topic of relations kept emerging as a central theme in our material, and our inductive approach allowed us to bring in the concepts with the most explanatory power. Dick has provided a good account of a similar way of applying a theoretical concept to explain emerging topics (Dick 2006).

In this project, two researchers conducted ethnographic field work (Agar 1985). The methods used were participant observation, informal conversational interviews, unrecorded formal interviews, recorded interviews and also mail correspondences with informants from the ship after the voyages ended.

Both researchers took their departure from a joint field diary guide that listed the topics they needed to address. The tasks were to account for the organizational structure, hierarchy and manning of the ship, to find out what the safety practices were like (how many drills, how many meetings of the safety committee, etc.) and to talk to a variety of officers and ratings to learn about their experiences and attitudes towards safety, as well as life at sea and what it was like to work with colleagues of a different nationality. It was equally important, however, to be sensitive to the topics that emerged from the crew and from what the researchers experienced on board. On most voyages, the voyaging researcher also conducted formal and recorded interviews with a variety of the seafarers on board the ship. These interviews were conducted using a joint interview guide that was customized to the situation on the ship (an example is that two of the ships had a full crew, so everyone shared the same nationality, which made some of the questions irrelevant), and, again, the voyaging researcher was sensitive to emerging topics. See Grøn and Knudsen (2011) for a more elaborate description of the fieldwork.

After the data creation process, the researchers coded all materials (field diary notes, interviews, mails) in the software program NVivo in several steps; first, we agreed to attend to a number of nodes (topics) based on the project description and literature review. Then, we coded a sample of the materials according to the agreedupon nodes, while we also created new nodes to cover the emerging topics. We compared nodes, discussed the coding, came up with a new set of nodes and recoded the data. Then, the rest of the material was coded.

One of the emerging nodes with many sub-nodes was "relationships"; thus, we decided to use the concept of social capital as a theoretical framework and invited the second author into the discussion. The next step was to pinpoint the ship as the analytical object and, from there, select the excerpts that could add to theory development and also form a narrative. We selected data from four of the five voyages. Table 2 gives an overview of the voyages.

We analyzed the data and then selected descriptions and quotations stemming from at least three different data collection sources and from people in both high- and low- 
Table 2 Info on the 5 Danish international vessels in the research project

\begin{tabular}{|c|c|c|c|c|c|c|c|}
\hline Type & $\begin{array}{l}\text { Crew } \\
\text { size }\end{array}$ & $\begin{array}{l}\text { Crew } \\
\text { nationality }\end{array}$ & Organization type & $\begin{array}{l}\text { Duration } \\
\text { (days) }\end{array}$ & Year & Researcher & Included? \\
\hline Coaster ship & 6 & Mixed & $\begin{array}{l}\text { Small family } \\
\text { owned company }\end{array}$ & 7 & 2010 & First author & $\mathrm{X}$ \\
\hline Oil tanker & 24 & Full (Indian) $^{\mathrm{a}}$ & $\begin{array}{l}\text { Large multinational } \\
\text { company }\end{array}$ & 15 & 2011 & First author & $X$ \\
\hline Cargo ship & 13 & Full (Danish) & $\begin{array}{l}\text { Medium sized } \\
\text { outsourced } \\
\text { national company }\end{array}$ & 11 & 2011 & Colleague & $\mathrm{X}$ \\
\hline Reefer ship & 15 & Mixed & $\begin{array}{l}\text { Large multinational } \\
\text { company }\end{array}$ & 21 & 2010 & Colleague & \\
\hline $\begin{array}{l}\text { Passenger } \\
\text { ship and } \\
\text { Ro/Ro }{ }^{b}\end{array}$ & 180 & Mixed & $\begin{array}{l}\text { Large international } \\
\text { company }\end{array}$ & $20^{\mathrm{c}}$ & 2010 & $\begin{array}{l}\text { Both first } \\
\text { author and } \\
\text { colleague }\end{array}$ & $X$ \\
\hline
\end{tabular}

${ }^{a}$ Crew consisting of seafarers of the same nationality

${ }^{\mathrm{b}}$ Roll on/roll off. Here a ship transporting passengers, trucks, cars, and cargo

${ }^{\mathrm{c}}$ Both researchers at the same time in 10 days

ranking positions. Our aim was to provide as many perspectives as possible to give an impression of the rich variance across the sample space outlined in Table 3 below. Notice, however, that the eight outcomes depicted in the table (with our Danish cases plotted in the sample space as well) of $\mathrm{BO} / \mathrm{BR} / \mathrm{LI}$ configurations imaginable appear when we look solely at the presence or absence of types of capital, that is, at the assessed quantity of each type of social capital, structured in a space of low/medium/high values on the horizontal axis and low/high values on the vertical axis. As we will show in the following, the quality of the types of social capital (positive or negative) is crucial as well.

Table 3 Blue social capital: configurations of bonding (BO), bridging (BR) and linking (LI) types of social capital among crews

\begin{tabular}{|c|c|c|c|}
\hline & $\begin{array}{c}\text { Horizontal networks } \\
\text { LOW }\end{array}$ & $\begin{array}{c}\text { Horizontal networks } \\
\text { MEDIUM }\end{array}$ & $\begin{array}{c}\text { Horizontal networks } \\
\text { HIGH }\end{array}$ \\
\hline \multirow{2}{*}{$\begin{array}{c}\text { Vertical } \\
\text { networks } \\
\text { LOW }\end{array}$} & \multirow{2}{*}{$\begin{array}{c}0 \\
\text { CARGO SHIP }\end{array}$} & $\mathrm{BO}$ & \multirow{2}{*}{$\begin{array}{c}\text { BO, BR } \\
\text { TANKER SHIP }\end{array}$} \\
\hline & & BR & \\
\hline \multirow{2}{*}{$\begin{array}{c}\text { Vertical } \\
\text { networks } \\
\text { HIGH }\end{array}$} & \multirow{2}{*}{ LI } & $\begin{array}{c}\text { LI, BO } \\
\text { COASTER BOAT } \\
\text { PASSENGER SHIP }\end{array}$ & \multirow{2}{*}{ LI, BO, BR } \\
\hline & & LI, BR & \\
\hline
\end{tabular}


The sample we have chosen is very limited for the purpose of giving a multispectral account. We have, however, attempted to present what is, to our knowledge, a relatively representative sample, containing rather typical crews and ship sizes and types. Thus, the selection criteria for the four international ships we explore here were that they should be both typical and, at the same time, illustrative of various configurations of social capital. As mentioned, these organizational patterns were found fully through induction, and it was after data collection that we developed a social capital framework that seemed apt for explaining and deepening an understanding of our empirical findings. To further simplify things, we chose to analyze the cases by primarily focusing on the existence/lack of various types of social capital rather than assess the quality of them (negative or positive).

\subsection{Bonding and linking, but no bridging social capital: the coaster}

\subsubsection{Background}

The first vessel was a small coaster owned by her Danish ${ }^{5}$ Master and his wife. Their son was also on board as a trainee, along with a Polish AB, a Filipino cook/AB, and two Filipino officers. The Filipino and Polish seafarers were hired through manning agencies. The family strove to retain their crewmembers and thus offered a bonus on their return, but at the time the first author was on board, there were three new crew members, as the Pole and the two Filipino officers had signed on for the first time. Thus, the vessel was a small business with a simple organizational structure and a few male crewmembers of diverse nationalities. The specialty of the coaster was that it could enter the small fiords of the North Atlantic Ocean, and its cargo was often building supplies. However, the fieldwork took place in the midst of the economic crisis, and the family lost money sailing around and waiting for customers; sadly, the company went bankrupt shortly after the fieldwork was completed.

The social capital configuration on the coaster was marked by negative bonding and power conflicts, which endangered not only productivity but also safety on board, as we shall see. Linking, however, was easy, as the owner was part of the crew.

\subsubsection{Report from the field}

We start with a dramatic event recorded in the first author's field diary:

The arrival was dramatic. We headed for a small port at the bottom of a Norwegian fjord full of small islands and shallow waters. At the bridge, the captain was at the helm, the first mate handled paper work, the young trainee kept lookout, and I was drinking coffee. The captain tried to contact the port authorities at shore on the radio without success. He then started searching for a printout of a mail that contained the cell phone numbers of the personnel at the port (the port had only a few staff members with many duties) while steering at

\footnotetext{
${ }^{5}$ For the purpose of this paper, we regard the former colonies of the Faroese islands and Greenland as part of Denmark, though they both are in the process of gaining independence.
} 
the same time. He needed to get in touch with the port staff to learn where to moor exactly, because his replacement had hit the pier and damaged the ship the last time they called at this port, and he did not want to repeat that. The Captain then asked the first mate to steer, so he could look for the mail. He had been explaining the situation to me in Danish, but to the first mate he just gave a short command. To me it sounded like he said, 'Take over'. The first mate did so and asked, 'I just go straight, Captain?' The captain, who was busy sorting through papers, mumbled something which sounded like, 'Yeah, you just follow the course'. The first mate did not seem to fully comprehend the situation, but he did not say anything. The first mate then led the ship straight ahead, which brought us north of the planned course and close to some rocks in a shallow part of the fjord. Suddenly, the captain looked up and exclaimed 'What are you doing?' He quickly switched to manual steering and adjusted the ship. He was shaken.

Later the captain insisted on being part of the safety committee's meeting, though the meetings were normally held without him. He took the opportunity to bring the incident forward in a formal setting in front of the whole crew, leading to a power play between the two with two central themes: navigation, in which the first mate had made a grave mistake, and a safety drill. The following passage from the field diary has been shortened to a few central sentences that reflect the core of the much longer exchange of words:

We have just had a safety committee meeting and a drill. The Captain brought the incident from the arrival forward. He said that the first mate had nearly grounded the ship. When the first mate defended himself by asking how come he had left him at the helm then, the captain replied, 'Because it is your job'. When it was time for the drill, the captain intervened in the first mate's way of conducting the drill: The captain wanted the unannounced drill to take place later, without warning, while the first mate (who was in charge of drills and head of the safety committee) maintained the opinion that a truly unannounced drill is not feasible on a small ship without loudspeakers. The other Filipinos supported the first mate by uttering small sounds rather than spoken words, and he looked at them for support. In the end, the first mate gave in. He said that they would do it the way the Captain had said from now on, because 'the Captain wants it that way'. The young trainee suggested a face-saving compromise, which everyone agreed to: to have a cup of coffee and then the drill.

The first author had been talking quite a bit with the captain on the bridge, and the captain told her about the many challenges he faced as owner of a small coaster with so few crew members and a difficult economy. Because she also wanted to know what the first mate's thoughts were, she grabbed the opportunity to go ashore for shopping and eat a pizza with him and the chief engineer. As hoped, they opened up a little when they were away from the ship, though they were still cautious with their words. The following is a field diary summary of this informal conservational interview with the first mate and the chief engineer (both Filipinos): 
They obviously stick together, they are both new to this type of ship, they are used to larger ships with more colleagues and more distance from the company owner, they told me. When I told them that I had been scared before coming aboard because it was my first time, they said that they still feel insecure before signing on every time they have a new contract. The worst is when a captain is mad and angry; luckily this one isn't, they said, but the system is a little strange. They have never before tried a system in which the owner and the captain are one and the same person. It puts more pressure on them, because the employer is close by and watches everything and wants to save money.

When the first author returned from the voyage, she wrote a short note with recommendations for the captain at the request of his wife and suggested, among other things, speaking only in English to avoid leaving anyone out. He was a bit provoked by her suggestions and mailed the ethnographer a reply from which the following quote stems:

You were there when we had that meeting on the bridge. Perhaps you noticed that they switched to their own dialect a couple of times. I did not speak Danish, and Peter did not speak Polish. My relationship to seafarers of Filipino descent has (previously) been so close and so good that we have been invited to their homes. It is a fact that a white person (Danish or Faroese) conforms easier to foreign seafarers than Filipinos. It is a problem that neither you, nor me, can solve. It is the seafarer from the Philippines himself, who must solve that, and also they need to learn that the crab mentality they have is useless on board a ship, especially a ship of this size.

Even though the captain owned the ship and was thus employer as well as master, his position was threatened, and he struggled to keep everything together and maintain his authority. One of his problems was that he did not know the two officers well, and he doubted their competence.

The term "crab mentality" is interesting. It reflects the widespread belief that Filipinos are more family- and community-oriented than westerners-something that further nurtures negative stereotyping.

Fig. 1 Social capital configuration on the coaster

\section{THE COASTER}

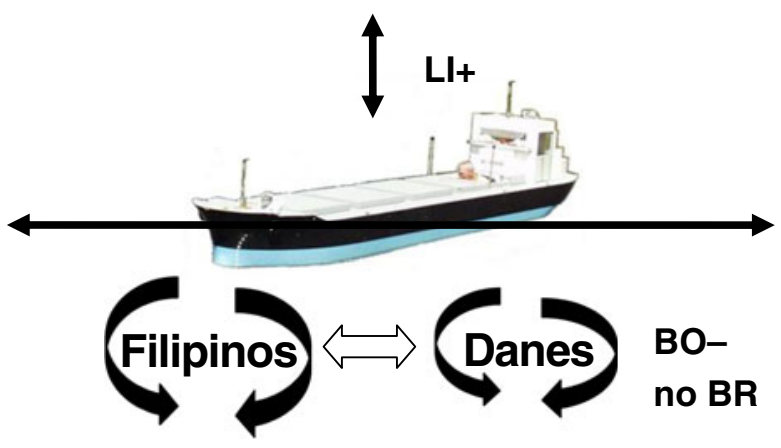


In sum, what we see here is an example of excessive bonding social capital - the Filipinos sticking together, the Captain and his son, the trainee, also sticking together, and the Polish AB floating around in between. This type of social structure makes building bridging social capital very difficult. Whatever the epistemological perspective, the Captain of the coaster was challenged by the community his Filipino crew members formed, resulting in lowered work performance, distrust, conflicts, misunderstandings, lowered security on board, lowered work performance and, ultimately, lowered economic performance (see Fig. 1).

\subsection{Bonding and bridging, but no linking social capital: the tanker}

\subsubsection{Background}

The second vessel was an oil tanker that sailed for a large company with offices all around the world and their own manning agencies in both Mumbai and Manila. The crew was a full crew of 24 Indian male seafarers, and there were two main departments on board: the machine and the deck. When the first author was on board, the first engineer's wife and son were also on board as passengers. The most striking experience was that the Master and his crew felt "distant" because they did not have anyone on board with a close connection to the Danish shore organization. Their marginalized position also gave rise to a feeling of being less valued than Europeans. The first author's impression was that the crew and the ship were well-functioning. Some of the ratings did, however, draw her attention to the relations between the ratings and the officers, about which they were unhappy. For the purpose of this paper, however, we have chosen to focus on the scarcity of relationships between the shore office and the ship, which led to a "blue" social capital constellation consisting of positive bonding and (overall) positive bridging but lacking linking.

\subsubsection{Report from the field}

One day, when the first author had ten o'clock coffee with some of the ratings in the mess, they took the opportunity to tell her about some things that they wanted her to pass along to the "back office". She had explained that she did not work for their employer, but they still felt that she could get their messages out better than they could. She described the informal conversational interview in this way in her field diary:

The ratings said that 'mixed crews are better', because foreign officers are more considerate and helpful and talk nicer to them. They also argued that it would be better if seafarers returned to the same ship instead of having a new workplace and new colleagues with every new contract, because that way the officers would have to solve the conflicts, as they would know they would be facing the same people after their home leave. As it is now, the officers sometimes do not bother.

Later, the first author, the bosun, and an AB kept watch as the oil was unloaded, a long and tedious process that went on for hours, giving them good opportunities to 
talk. The AB revealed some of his concerns, which the first author recorded when the watch was over:

On our watch with Joe yesterday, Joe told me about himself. The man is desperate to come home. He thought he would be signing off in this port, but now he has been informed that it is not possible because the manning office cannot find a replacement for him. He had told his family that he would come home. His sister will leave her parents-in-law without care and walk $15 \mathrm{~km}$. to meet him at their parents' house, so he feels bad about letting her sit and wait in vain for him.

The next morning at breakfast, the first author discussed the matter with the master. Later, she recorded the conversation in her field notes, from which the following passage stems:

When I had breakfast with the master, I told him about Joe's hardships. The master told me that he does not get any information about such matters. It has been two months since he asked permission to sign Joe off at this port, but he did not get any confirmation notice or anything. It is the same with the second engineer, who wanted to extend his contract. He has not been told whether that is possible; all he receives is a plane ticket without explanation, and then he must figure the rest out. During some of his contracts, he has had the power to sign people on and off, which is better, as he is not interested in having seafarers on board against their will. But on this contract he has no say. That means that he also cannot tell people the reason why they cannot come home or extend their contract. The officers get double pay for the additional days they have to stay when their contract has run out, but the ratings do not. A rating's contract is for nine months plus/minus a month; in reality, it is often plus a month and never minus.

The next day, when the first author found herself in the galley with both Joe and the master, she took up the matter and later recorded the following events in her field diary:

I asked Joe for news. The master was also present, and he said jokingly, 'Ah, don't encourage him, now he will be on my back about this all the time'. But he did tell Joe that he thought he would be signed off in the next port; he was only waiting for confirmation. Joe was thrilled to be informed, even if it was not certain yet. He thanked me. He seemed to hold the impression that I had put pressure on the master to send him home, but neither of us can do anything. Maybe he just appreciated being informed. In any case, he has been transformed from a desperate man to a happy one.

Two types of relationships were predominant during the fieldwork on the tanker: the relationship between the far-away back office in Denmark and the somewhat detached ship, and the relationship between the officers and the ratings. The first sort of relationship lay beneath every other complaint and was also formulated by the master in various ways, while the relationship 
between the officers and ratings was something that the ratings brought up when the first author had gained their trust. The fitter on board touched upon both these relationships in an interview. He was a man of manners and intelligence who, in fact, seemed overqualified for a rating's position. He was also quite outspoken. He had shared many of his opinions with the first author, but in the formal situation of a taped interview, he held back. In the end, she asked him if there was a question that he thought she should ask, and there was:

Fitter: The first question I think you should ask the crew is: 'Are you happy with the company or not?' [laughing]

Interviewer: Yes. I never asked anyone that but I can ask you now: 'Are you happy with the company or not?'

Fitter: Yeah, but I am happy with this company-I can understand the reputation of the company. Now when it comes to like these people-like those who are in Denmark, they don't come and visit us.

Interviewer: No?

Fitter: We are just directly put through to the Indian staff, so whatever we want to speak with them about, like when, what we have of insight, when, if we tell them, it is no use.

Fitter: The company's policy is that they don't have electricians on board. So for that, the officers and engineers have been paid extra. Now we have a trainee electrician, who does almost all the jobs. When he was not there, I was doing the job-like anything, lights on the deck. I was not paid any extra for that - the second/shift engineer will tell me, 'You should go and do it'-I shouldn't. Now we have an electrician. He is paid around seven hundred dollars, and the officers and engineers are still paid. If they give this money to him instead of them, I think that he will take more interest in the job, and he will try to pick up more things, and why these things

Fig. 2 Social capital configuration on the tanker

\section{THE TANKER}

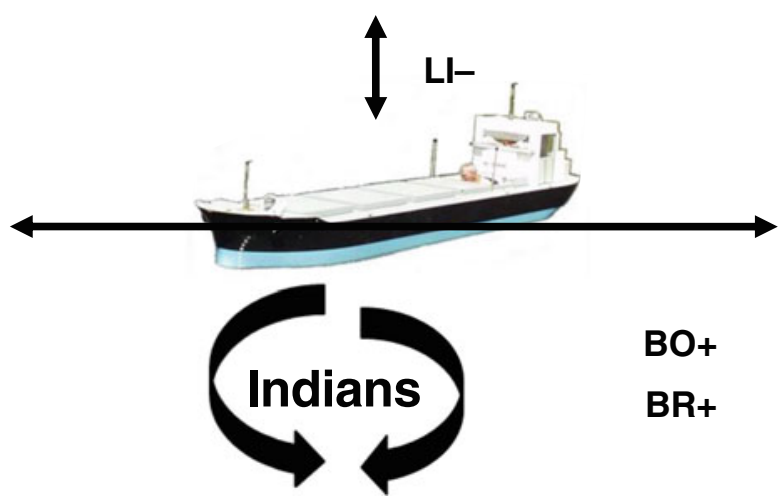


are happening, I don't understand. And we don't have anyone to question about this.

In sum, the tanker ship was in a special situation because the shipping company had obtained a dispensation from the usual requirement of having at least one European officer on board. As a result, the connection to the shore-based part of the shipping company was weak, and the social capital configuration was positive bonding and bridging but clearly suffered from lack of linking. One of the consequences is that the master had difficulties in exercising his authority, and the relationships between the officers and ratings were also affected (Fig. 2).

\subsection{Bonding and linking, but no bridging social capital: the passenger ship}

\subsubsection{Background}

The third vessel was a Ro/Ro and passenger ship ${ }^{6}$ with Danish top officers and 180 crewmembers from 13 different nationalities and of both genders. The company had many routes and used manning agencies for hiring crew members. The ship had four departments: the deck, the machine, the catering department and the accommodation department. Both the first author and her colleague were on board. They engaged in two departments each to cover as much of the ship as possible. The important emerging topics were discrimination and the lack of equality between crew members. The configuration of social capital was positive bonding and linking, but there was a lack of bridging across departments and national groups. The data we present here were collected by both researchers.

\subsubsection{Report from the field}

On the large ship, one of the first things that caught the researchers' attention was the visibility of the ship's hierarchy, here recorded in the field diary of the first author's colleague:

The service personnel are obviously lowest in the hierarchy. Their cabins are on deck two, and they are small and dark because there are no windows. Those cabins are claustrophobic. They also have the lowest pay, many different tasks and shorter breaks than, for instance, the people in the machine room, who have half an hour for 10 o'clock coffee.

The first author also became interested in the way the employees were said to be treated equally. In reality, there was a graduation of equal treatment, meaning that all were addressed politely and equally by the officers, but the employment conditions shone through and had a stratifying effect, as was

\footnotetext{
${ }^{6}$ Roll on/Roll off, which means that cars, trucks and containers can roll on and off from the car deck.
} 
revealed in an informal conversation with a Polish motorman, recorded in the field diary:

When the Polish crew members sign on or off, they are transported by bus. Bogdan (Polish rating) told me that the bus leaves at $6 \mathrm{pm}$, but he is not home until midnight the day after. Søren (Danish officer) was present when we talked about it. He didn't seem to believe that it could be that bad, but Bogdan did not take it lightly, I could hear. He argued that it is a tough ride. The bus is slow and stops for a break every two hours, sometimes for 45 minutes. And he doesn't sleep well in the bus. It also added to his frustration to know that with a cheap Easy Jet ticket, he could be home in four hours.

The first author's colleague brought up the issue in a recorded interview with a Filipino rating - a cabin steward:

Interviewer: And what about the differences in wages? For the same work you get different wages.

Cabin steward: Yes, yes. We cannot do anything about this, it's between the agency and our principal.

Interviewer: But how does it feel? Is it something you think about when you work together? And the length of the contract also...

Cabin steward: Sometimes it... ah sometimes it is a little bit sad, because if you compare, so... for me, in my opinion, I don't compare, I just close my eyes. Close my one eye for it. Because Polish accept Euros, Danish accept Euros, British entertainers, they get pounds, but we only get dollars. So for that kind of situation, I close my eyes. I accept the truth that I am Filipino, they are Europeans. That's it.

Fig. 3 Social capital configuration on the passenger ship

\section{THE PASSENGER SHIP}

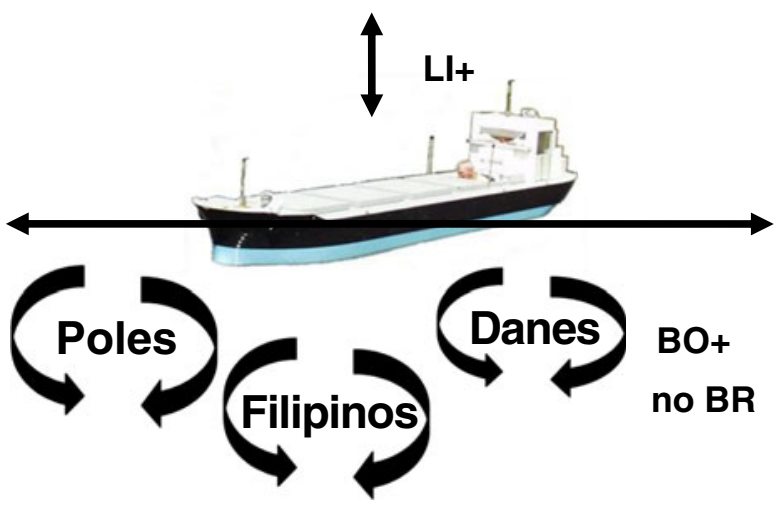


Hence, in this passenger ship in which many nationalities worked together under different conditions, we see that both the shipping company and the master made efforts to treat everyone equally. However, both were counteracted by the structural work conditions of the people on board. Thus, in this social capital configuration, linking was present and bonding was positive, but bridging was lacking. In other words, collaboration across groupings and departments was scarce, reinforced by both economic inequality and physical segregation. This also meant that some important safety information was not shared between the deck and the machine department (Fig. 3).

\subsection{The cargo ship}

\subsubsection{Background}

The fourth vessel was a dry cargo ship. The company had previously been state owned and had a monopoly on transport in the water in which the vessel serves today. In contrast to the previously described ships, all 13 crew members (12 male and one female) belonged to the same nationality, and all but the female were on permanent contracts and affiliated with the same ship. Thus, they were directly employed by the shipping company without the usual extra link of a manning agency. When the first author's colleague was on board, the ship was, however, in a transition process, and a shift from fluent to set wages had created a tense atmosphere between officers and ratings over work hours. Such a situation is abnormal; thus, the data must be interpreted cautiously and regarded as specific to this voyage. We have, however, chosen to include the data because they illustrate how productivity is affected by lack of social capital and poor working relationships. The configuration of social capital in this situation was, in fact, near absence of all three types of social capital. We do not, however, have any records of linking, so we cannot be certain of the quality of the relationship between the shore office and the ship. It is possible that the many conflicts on board simply overshadowed the linking relationships.

\subsubsection{Report from the field}

It took about a week before the conflicts over the wage system became apparent to the first author's colleague. The first record she made of it in her field diary stems from a conversation with the cook:

The cook told me that there are 13 crew members. Eleven are mandatory, so they have a surplus of two. Everyone, except for the stewardess, has set wages. The ABs have had that for a couple of years. The system has advantages as well as disadvantages. Some people are hard to motivate to perform more than just the routine tasks, as they are no longer paid to do them specifically.

When the researcher had worked for some time alongside the ratings, they also started to express their discontent. She recorded the following observations in her field diary:

Flemming is discontent because he does not get his obligatory six rest hours in a row. He complained to the first engineer, though he is not his superior. When he 
said it to me, I suggested he talk to his superior, but he said that he had already done that; they have a different interpretation of rest hours. I suggested that he should contact his union, but he just mumbled something. He does not seem to belong to the brightest types; for instance, when he came to help me with my fairlead, he took the smallest package, the one I could lift myself. My impression was confirmed during the coffee break, when the captain asked me if I had learned to work slowly.

When the conflict was detected, it became clear to the researcher that the captain was part of it too- but from the opposite side. Here is an extract from the diary of an informal, conversational interview with the captain:

I told the captain that I would prioritize interviews with the ratings, because they are an endangered species (Danish ratings, that is). It was like pushing a button, which started a torrent of words about Danish ratings. It is their own fault, they are lazy, there's always argy-bargy with them: 'We cannot do this, we cannot do that, we cannot work longer'... Well, not each and every one, but $90 \%$. And also the current crew members, they are almost the worst. He started as an AB himself, but that was at a time when ABs could work. Now they seem to have lost their professional pride. He has sailed with other ratings: Black Cape Verdeans Faroese and Greenlandic, but the Danish are the worst. They take no initiative and, yes, it has become worse with the new agreement and set wages.

When the researcher started to pay attention to the conflict about working hours, she learned that the conflict must have been going on for quite a while because the two sides, the officers and the ratings, had firm but very differing pictures of the situation. This difference was revealed in a conversation with Flemming, the AB mentioned above. In the field diary, one reads:

It was okay to begin with. Flemming told about his job. He said they are fewer and fewer to do still more. He was fed up with it all. It was quite windy, and the visibility was low, so I asked if they did not keep lookout at the bridge today. Flemming said that they did not, because it is a work day. If it had been a Sunday, they would certainly have insisted that we kept lookout. Since they had set wages, well, I cannot remember his exact words, but the essence was that they keep them working to the limit. One of the other ABs, whom I have interviewed, said almost the same. It sure is another version than the captain's!

The researcher noticed that every small incident and new task was interpreted in light of the conflict and created resistance, as is typical of a prolonged conflict. Such a situation is unproductive and might even influence safety, as the researcher's diary record tells:

That it is becoming a matter of principle, I understood this morning. I am sitting in the crane house and I see a loose bar near a freshly painted yellow window frame. I show it to Tom upon his return. Yes, he says, Flemming just painted 
that. It is still another of their fancies, as it was not obvious enough that it is an escape route with the sign [apparently the ratings have been given the job to paint all escape routes yellow as part of the company's safety policy, but the ratings interpret the order as a meaningless job, since there already is a sign stating that the window is an escape route]. I do not object, as I think that the management might have had orders to paint all escape routes in the same color, which could be wise enough, but the atmosphere has become so infected that the ratings believe the officers are giving them tasks just to keep them busy.

A cook often takes a middle position on board, and, as such, the observant cook was able to reflect on the situation and explain some of the underlying behavioral motivations to the first author's colleague. In her field diary, one reads the following account of a conversation with the cook:

After the three o'clock coffee, I had a talk with the cook about the relations between officers and ratings. He asked me how my field work had been. 'Well there are some conflicts...' 'So, you have noticed that?' he replied. 'As I cook I hear both sides', he said. And then we talked about the two different perspectives (the cook's words): How the ratings do not consider that the officers get orders from the shipping company, and that it is difficult for the ratings to speak openly as they are constantly afraid of losing their jobs.

We end this report from the conflict zone with a record of the unproductive consequences of job uncertainty and infected work relations, as explained in an interview with the first engineer, who had difficulties in getting the information he needed to keep the machines running smoothly:

Interviewer: I have heard that the company is chasing near misses, and that you are scolded if you do not make any.

First engineer: Yes, it is silly.

Interviewer: Sure, but do you think that some hide it?

First engineer: They do. I am in charge of maintenance of the machine, and it often happens that something breaks down for some reason. No one tells me. People wonder, how did it happen? And then someone is blamed. Then they

Fig. 4 Social capital configuration on the cargo ship

THE CARGO SHIP

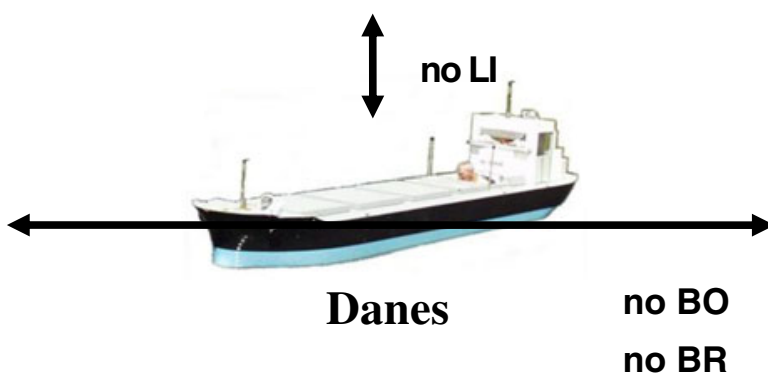


might say that it was someone from the last shift. And sometimes, then something has happened that makes one think: why on the earth did you do that? They do not tell if they break something.

Interviewer: That's quite peculiar. It is exactly the same I hear about Filipinos.

First engineer: It is exactly the same here [among the Danish crew]; they do not tell.

To summarize, in this ship, we see a configuration of social capital in which the working environment is so infected by conflicts that social capital is missing, and the effects on productivity and safety on board are severe (Fig. 4).

\section{Conclusion}

Most people in the shipping sector know that poor cooperation on board or between crews and shipping companies lowers work performance and profitability. Lack of cooperation within a crew may even threaten safety on board. This tendency is reinforced by increased globalization, which entails that seafarers are seldom members of the same crew two voyages in a row and therefore have to cooperate with a multitude of colleagues whom they do not know and whose primary language they may not understand (Progoulaki and Roe 2011). However, the fact that everybody knows about such problems does not mean that everybody knows what to do about them. Hence, we wanted to answer the question: How can fragmentation of "blue" social capital due to globalization be counteracted?

The particular importance of cooperative skills in this sector makes it reasonable to talk about a specific type of maritime social capital, or "blue" social capital. Here we have understood "capital" to be wealth that renders its owner revenue without immediately being destroyed itself in the production process and "social capital" as an intangible form of capital consisting of resources inherent in network cooperation associated with norms of reciprocity and trust (Putnam 2000: 19) which — unlike tangible assets - increases with use.

Hence, to answer the research question, we developed and applied a "blue" social capital framework as a concrete tool for understanding and analyzing maritime cooperation in a systematic way. We used anthropological fieldwork data from four Danish international ships to map and analyze what we termed "configurations of social capital", i.e., various combinations of three types of social capital (Szreter and Woolcock 2004). These are horizontal networks on board the ships in the form of bonding (BO) and bridging (BR) social capital, as well as vertical networks in the form of linking (LI) social capital. All three types contained "both sides of the coin", that is, a productive "sunny" and an unproductive "shadow" side. BO was associated with homogeneous, exclusive identities (e.g., groups of Poles or Filipinos), while BR was defined as open networks including the whole crew. LI was operationalized as bridging networks between crews and the shipping company.

Overall, our empirical findings show that it is crucial for captains and shipping leaders to try to obtain a balanced mix of the BO, BR and LI types of social capital to secure productivity and happy crews. None of the types of capital can be left out. Rather than letting crews "sail their own boat", leaders within the maritime sector should carefully plan how to foster the three types of social capital inside the 
company, both at sea and ashore. In this way, the leaders can strengthen the quantity and quality of "blue" social capital. We have argued that, although it is an intangible form of wealth, "blue" social capital has visible economic effects, just like other, more conventional forms of capital within this sector, e.g., ships, containers, harbor facilities, electronic technology and maritime education. Hence, a large and wellbalanced stock of "blue" social capital can increase psychological well-being, safety, work performance and, ultimately, economic performance.

Acknowledgments This article is one of the outcomes of the project Safety Culture and Reporting Practice on Board Ships in the Danish International Ships Register (SADIS), financed by The Danish National Work Environment Foundation. We warmly thank our colleague Fabienne Knudsen for creating some of the data presented here and for encouraging us to make use of it.

Open Access This article is distributed under the terms of the Creative Commons Attribution License which permits any use, distribution, and reproduction in any medium, provided the original author(s) and the source are credited.

\section{References}

Agar M (1985) Speaking of Ethnography. Sage, Hollywood

Barbalet J (2009) A characterization of trust, and its consequences. Theor Sociol 38:367-382

Bjørnskov C (2009) Economic growth. In: Svendsen GT, Svendsen GLH (eds) Handbook of social capital. Edward Elgar Publishing, Cheltenham, pp 337-353

Blau PM (1964) Justice in social exchange. Sociol Inq 24:193-206

Bourdieu P (1986) The forms of capital. In: Richardson JG (ed) Handbook of theory and research for the sociology of education. Greenwood, New York, pp 241-258

Coleman JS (1990) Foundations of social theory. Harvard University Press, Cambridge

Coleman JS (1994) A rational choice perspective on economic sociology. In: Smelser NJ, Swedberg R (eds) The handbook of economic sociology. Princeton University Press, New York, pp 166178

Cook K, Hardin R, Levi M (eds) (2005) Cooperation without trust? Russell Sage Foundation, New York

Dasgupta P, Serageldin I (eds) (2000) Social capital: a multi-faceted perspective. The World Bank, Washington

Dick P (2006) The psychological contract and the transition from full-time to part-time work. J Organ Behav 27:37-58

Dudwick NK, Kuehnast K, Jones VN, Woolcock M (2007) Analyzing social capital in context: a guide to using qualitative methods and data. The World Bank, Washington

Emerson RM (1976) Social exchange theory. Annu Rev Sociol 2:335-362

Etzioni A (2003) Toward a new socio-economic paradigm. Socio Econ Rev 1:105-118

Gittell JH, Seidner R, Wimbush J (2010) A relational model of how high-performance work systems work. Organ Sci 21(2):490-506

Gouldner A (1960) The norm of reciprocity: a preliminary statement. Am Sociol Rev 25(2):161-178

Granovetter MS (1973) The strength of weak ties. Am J Sociol 78(6):1360-1380

Grøn S, Knudsen F (2011) Fieldwork on board ships: a look inside the ethnographer's workshop. Mercator June 2011:363-368

Grøn S, Knudsen F (2012) Why do Filipinos have fewer reported work accidents than other nationals? Findings from literature. Int Marit Health 63(2):96-101

Grootaert C, Bastelaer TA (eds) (2002) Understanding and measuring social capital. A multidisciplinary tool for practitioners. The World Bank, Washington

Hardin R (2002) Trust and trustworthiness. The Russell Sage Foundation, New York

Homans GC (1961) Social behavior: its elementary forms. Harcourt, Brace \& World, New York

Huang J, Fox MS (2006) An ontology of trust-formal semantics and transitivity. ACM Int Conf Proc Ser $156: 259-270$

Huck S (1998) Trust, treason, and trials: an example of how the evolution of preferences can be driven by legal institutions. J Law, Econ Organ 14(1):44-60 
Knack S, Keefer P (1997) Does social capital have an economic pay-off? A cross-country investigation. Q J Econ 112:1251-1288

Lane T (1996) The social order of the ship in a globalised labour market for seafarers. In: Crompton R, Gallie D, Purcell K (eds) Changing forms of employment. Routledge, London

Mauss M (1969 [1925]) The gift: the form and reason for exchange in archaic societies. Routledge \& Kegan Paul, London

Newton K (2007) Social and political trust. In: Russell JD, Klingemann H-D (eds.), The Oxford Handbook of Political Behavior, pp 342-361

Ostrom E, Ahn TK (2009) The meaning of social capital and its link to collective action. In: Svendsen GT, Svendsen GLH (eds) Handbook of social capital. Elgar, Cheltenham, UK, pp 1735

Portes A, Landolt P (1996) The downside of social capital. Am Prospect 26:18-21, May-June

Progoulaki M, Roe M (2011) Dealing with multicultural human resources in a socially responsible manner: a focus on the maritime industry. WMU J Marit Aff 10:7-23

Putnam RD (1993) Making democracy work. Civic traditions in modern Italy. Princeton University Press, Princeton

Putnam RD (1995) Bowling alone: America's declining social capital. J Democr 6(1):65-78

Putnam RD (2000) Bowling alone. The collapse and revival of American community. Simon \& Schuster, New York

Putnam RD (2007) E Pluribus Unum: diversity and community in the twenty-first century. Scan Polit Stud 30(2):137-174

Rothstein B (2002) Sweden: social capital in the social democratic state. In: Putnam RD (ed) Democracies in flux: the evolution of social capital in contemporary society. Oxford University Press, Oxford

Rothstein B (2009) The universal welfare state. In: Svendsen GT, Svendsen GLH (eds) Handbook of social capital. Elgar, Cheltenham, UK, pp 197-211

Sampson H (2012) Globalisation, labour market transformation and migrant marginalisation: the example of the transmigrant seafarers in Germany. J Int Migr Integr. doi:10.1007\%2Fs12134-012-0266-0

Schröder-Hinrichs J-U, Hollnagel E, Baldauf M (2012) From Titanic to Costa Concordia - a century of lessons not learned. WMU J Marit Aff 11:151-167

Svendsen GT, Svendsen GLH (eds) (2009) Handbook of social capital. Edward Elgar Publishing, Cheltenham, UK

Svendsen GLH, Waldstrøm C (2013) Organizational networks and social capital. In: Caulkins DD \& Jordan AT (eds.) Companion to Organizational Anthropology, pp. 311-328. Blackwell

Szreter S, Woolcock M (2004) Health by association? Social capital, social theory, and the political economy of public health. Int J Epidemiol 33:650-667

Veblen TB (1908a) Fisher's capital and income. Polit Sci Q 23(1):112-128

Veblen TB (1908b) On the nature of capital: investment, intangible assets, and the pecuniary magnate. Q J Econ 1:104-136

Woolcock M (1998) Social capital and economic development: toward a theoretical synthesis and policy framework. Theory Soc 27:151-208

Woolcock M (2001) The place of social capital in understanding social and economic outcomes. Can J Pol Res 2:11-17 